\title{
Stagnant loop syndrome in patients with continent ileostomy (intra-abdominal ileal reservoir)
}

\author{
H. SCHJØNSBY 1 , J. F. HALVORSEN, T. HOFSTAD, AND N. HOVDENAK \\ From the University of Bergen, Medical Department A, Department of Surgery, The Gade Institute, \\ Department of Microbiology, 5016 Haukeland Hospital, Norway
}

SUMMARY Intestinal absorption and bacteriology of the ileal contents were compared in seven patients with continent ileostomy and seven patients with conventional ileostomy. The absorption of vitamin $B_{12}$ was reduced in five patients with continent ileostomy and subnormal in two patients with conventional ileostomy. Steatorrhoea was present in four patients with continent and one patient with conventional ileostomy. Increased concentrations of total anaerobic bacteria and Bacteroides were found in the ileum of the patients with continent ileostomy. After an oral dose of $\left[1-{ }^{14} \mathrm{C}\right]$ glycocholic acid there was no difference in the faecal excretion of radioactivity, whereas the ${ }^{14} \mathrm{CO}_{2}$-expiration was increased in two patients with continent ileostomy. In four patients with continent ileostomy and malabsorption of $\mathrm{B}_{12}$ there was evidence of a stagnant loopsyndrome, as oral lincomycin treatment resulted in increased absorption of $B_{12}$, decreased excretion of faecal fat, and decreased concentrations of Bacteroides in the ileum.

The continent ileostomy introduced by Kock (1969) is an alternative to the conventional ileostomy and makes use of an abdominal reservoir in which the intestinal contents are stored for several hours. Clinical studies have shown that the operation results in morphological changes in the reservoir with shortening of the villi (Philipson et al., 1975) as well as an increased number of microorganisms (Brandberg et al., 1972). It is, however, still uncertain whether the continent ileostomy leads to intestinal malabsorption. Jagenburg et al. (1971) found subnormal values of the Schilling test in six out of 10 patients with continent ileostomy, whereas the absorption of fat, d-xylose, and Lphenylalanine was the same as in patients with conventional ileostomy. In a subsequent study a low value in the Schilling test was found in only one patient of 34 with continent ileostomy (Jagenburg et al., 1975), and it was shown that the mucous membrane of the reservoir retained its capacity to absorb d-xylose and phenylalanine (Philipson et al., 1975).

In this study we present evidence of malabsorption because of a stagnant loop syndrome in four out of seven patients with continent ileostomy.

${ }^{1}$ Address for reprint requests: H. Schjønsby, Medical Depart-
ment A, 5016 Haukeland Hospital, Norway.

Received for publication 23 March 1977

\section{Methods}

\section{PATIENTS}

Seven outpatients with a conventional ileostomy (four women and three men, age range 28-61 years) and seven outpatients with a continent ileostomy (one woman and six men, age range 20-51 years) were included in the study. The postoperative observation period in the patients with conventional ileostomy varied between one to 110 months (mean 36 months) and in the patients with continent ileostomy between six to 52 months (mean 36 months). The indication for proctocolectomy was ulcerative colitis. In one patient with a continent ileostomy $15 \mathrm{~cm}$ of the ileum had been resected. In all the other patients less than $10 \mathrm{~cm}$ of the ileum had been removed. All patients gave their informed consent to the study, and were on unrestricted diet.

\section{PROCEDURE}

The study was conducted during two consecutive days. The first day the fasting patients were given orally $100 \mathrm{ml}$ orange juice containing $10 \mu \mathrm{c}\left[1-1^{14} \mathrm{C}\right]$ glycine-glycocholic acid and $5 \mathrm{~g}$ polyethylene glycol (PEG). To estimate the ${ }^{14} \mathrm{CO}_{2}$-expiration (breath test for deconjugated bile salts) breath samples were obtained before and each second hour after the meal (Fromm and Hofmann, 1971). Cumulative expiration in eight hours in control patients was 
$1.7 \%$ dose \pm 1.0 SD. Faecal contents (ileostomy effluents) were collected at three, five, seven, nine, 12, and 24 hours after the meal. Each faecal portion was homogenised, and duplicate samples obtained for determination of radioactivity (internal standard method) and PEG concentration (Hydén, 1955). The portions were then mixed for determination of faecal fat (Closs and Pihl, 1941). (Normal values $<6 \mathrm{~g} / 24 \mathrm{~h}$.)

The kinetics of the faecal excretion of radioactivity $\left({ }^{14} \mathrm{C}\right)$ and PEG were best described by a single exponential function. The logarithm of the fraction of the substances remaining in the body was plotted against time, and the elimination slopes were estimated by linear regression. The absorption coefficient for ${ }^{14} \mathrm{C}$-radioactivity was determined from the excretion constants of the two substances (Woodbury and Kern, 1971). The mean recovery of PEG as a percentage of the ingested dose was 91.2 (range 71.4-108.4) in patients with conventional ileostomy, and 90.9 (range 80.8-99.4) in patients with continent ileostomy.

The second day the patients were given $1 \mu \mathrm{g}$ $(0.5 \mu \mathrm{c}){ }^{57} \mathrm{CoB}_{12}$ for estimation of vitamin $\mathrm{B}_{12}$ absorption by the standard Schilling test (normal values $>8 \% / 24 \mathrm{~h}$ ).

Freshly obtained faecal samples for bacteriological studies were filled to the top in narrow-necked screw-cap test tubes containing $\mathrm{CO}_{2}$. Without delay 10 -fold dilutions $\left(10^{-2}\right.$ to $\left.10^{-8}\right)$ of the faecal samples, which were more or less fluid, were prepared in WAL diluent (Sutter et al., 1975). In triplicate $0.01 \mathrm{ml}$ of each dilution was spread with a standard loop on each of a series of agar plates. The series included blood agar (7\% human blood), Rich agar No. 12 (Drasar, 1967), lactose agar (Schjønsby, 1972), and blood agar containing kanamycin and vancomycin for cultivation of Bacteroides (Finegold et al., 1971). Colony counts were made after aerobic incubations for 24 hours at $37^{\circ} \mathrm{C}$ (total aerobes and coliforms), and anaerobic incubations for two days
(Bacteroides) or five days (total anaerobes) in GasPak jars $\left(\mathrm{H}_{2}+\mathrm{CO}_{2}\right.$ generator) (Baltimore Biological Laboratories).

\section{Results}

\section{ABSORPTION STUDIES}

The mean absorption of vitamin $B_{12}$ assessed by the Schilling test was reduced in patients with continent ileostomy compared with conventional ileostomy (Table). In the individual patients the Schilling test was reduced below $8.0 \%$ in two patients with conventional and in five with continent ileostomy. There was no difference in the mean faecal fat excretion in the two groups, but the excretion was raised above $6.0 \mathrm{~g} / 24 \mathrm{~h}$ in one patient (no. 4) with conventional and three patients (nos. 1,2 , and 6) with continent ileostomies.

The absorption coefficient of ${ }^{14} \mathrm{C}$-radioactivity as well as the mean cumulative expiration of ${ }^{14} \mathrm{CO}_{2}$ ('breath test') after giving $\left[1-{ }^{14} \mathrm{C}\right]$ glycocholic acid showed no difference in the two groups. In two patients with continent ileostomy (nos. 3 and 4) the expiration of ${ }^{14} \mathrm{CO}_{2}$ was increased compared with the patients with conventional ileostomy.

\section{BACTERIOLOGY}

There was no difference in the concentration of aerobic microorganisms in patients with conventional and continent ileostomy, whereas the concentrations of total anaerobic bacteria and Bacteroides were increased in patients with continent ileostomy (Fig. 1).

\section{EFFECT OF ORAL ANTIBIOTICS}

In four patients with continent ileostomy (nos. 1, 2,3 , and 4) and $B_{12}$-malabsorption oral administration of lincomycin hydrochloride ( $2 \mathrm{~g}$ daily in divided doses for four days) resulted in increased absorption of vitamin $B_{12}$ and decreased excretion of faecal fat (Fig. 2). In the two patients with con-

Table Comparison of absorption in patients with conventional and continent ileostomy

\begin{tabular}{|c|c|c|c|c|c|c|c|c|}
\hline \multirow[t]{3}{*}{ Patient no. } & \multirow{2}{*}{\multicolumn{2}{|c|}{$\begin{array}{l}\text { Schilling test } \\
(\% / 24 h)\end{array}$}} & \multirow{2}{*}{\multicolumn{2}{|c|}{$\begin{array}{l}\text { Faecal fat } \\
(g / 24 h)\end{array}$}} & \multicolumn{4}{|c|}{ 'Absorption' of $\left[1{ }^{-14} C\right]$ glycocholic acid } \\
\hline & & & & & \multicolumn{2}{|c|}{${ }^{14} C$-absorption coefficient } & \multicolumn{2}{|c|}{ Expiration $(\% / 8 \mathrm{~h})$} \\
\hline & Conv. & Cont. & Conv. & Cont. & Conv. & Cont. & Conv. & Cont. \\
\hline $\begin{array}{l}1 \\
2 \\
3 \\
4 \\
5 \\
6 \\
7 \\
\text { Mean } \\
\text { SD } \\
\text { P }\end{array}$ & $\begin{array}{c}24 \\
26 \\
8 \\
7 \\
20 \\
10 \\
7 \\
14 \cdot 6 \\
8 \cdot 4\end{array}$ & $\begin{array}{c}3 \\
3 \\
2 \\
6 \\
10 \\
9 \\
4 \\
5 \cdot 3 \\
3 \cdot 2\end{array}$ & $\begin{array}{l}2 \cdot 8 \\
2 \cdot 8 \\
1 \cdot 3 \\
8 \cdot 4 \\
2 \cdot 7 \\
2 \cdot 9 \\
2 \cdot 2 \\
3 \cdot 3 \\
2 \cdot 3\end{array}$ & $\begin{array}{r}6.8 \\
12.3 \\
2.2 \\
5.2 \\
3.5 \\
7.0 \\
2.6 \\
5.7 \\
3.5\end{array}$ & $\begin{array}{l}1.00 \\
0.98 \\
0.99 \\
0.94 \\
0.88 \\
0.91 \\
0.95 \\
0.95 \\
0.04\end{array}$ & $\begin{array}{l}0.94 \\
0.95 \\
0.97 \\
0.93 \\
0.93 \\
0.89 \\
0.93 \\
0.93 \\
0.02\end{array}$ & $\begin{array}{l}0.8 \\
0.7 \\
0.7 \\
0.7 \\
0.8 \\
0.5 \\
1.3 \\
0.8 \\
0.3\end{array}$ & $\begin{array}{l}0.8 \\
0.6 \\
7 \cdot 3 \\
2.0 \\
0.4 \\
0.2 \\
1.2 \\
1.8 \\
2.5\end{array}$ \\
\hline
\end{tabular}






Fig. 1 Concentration of bacteria $\left(\log _{10}\right.$ no. of bacteria $/ g$ ) in faeces of patients with conventional and continent ileostomy.

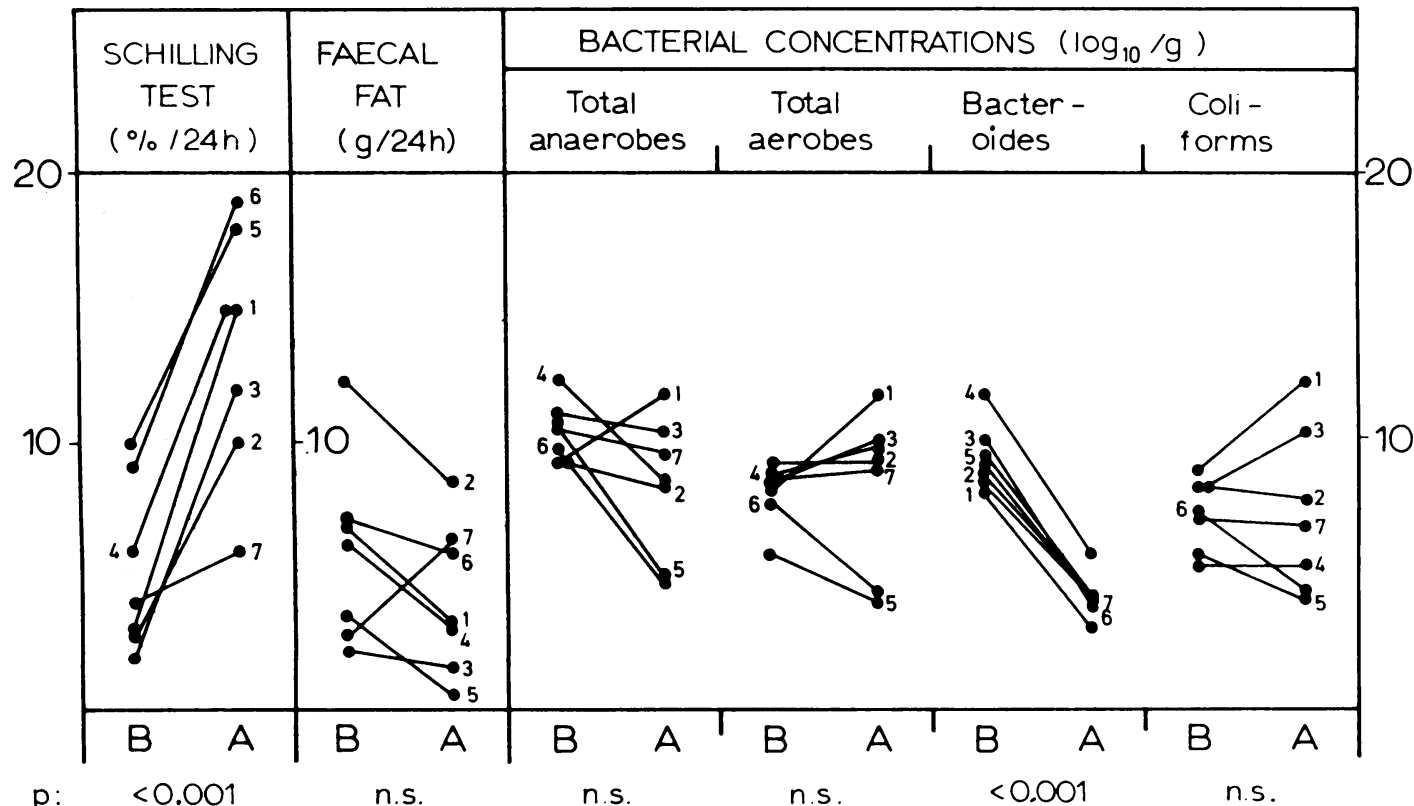

$p$

n.s.

n.s.

n.s

n.s.

Fig. 2 The effect of oral lincomycin treatment on the absorption and the bacteriology in patients with continent ileostomy. The numbers refer to the individual patients (B: before lincomycin. A: after lincomycin). 
tinent ileostomy and normal absorption of vitamin $B_{12}$ (patients 5 and 6) the absorption also increased. In patient 7 , who had $B_{12}$-malabsorption, the absorption of vitamin $B_{12}$ did not return to normal value, whereas the excretion of faecal fat increased. In all patients the concentrations of Bacteroides decreased, whereas the concentration of total anaerobes, total aerobes, and coliforms showed no significant change.

\section{Discussion}

The stagnant loop syndrome is known as an intestinal abnormality associated with bacterial overgrowth in the small intestine together with malabsorption of vitamin $B_{12}$ and steatorrhoea that improves with oral treatment with antibiotics (Tabaqchali, 1970). Stasis of the contents of the small intestine is also a feature of the stagnant loop syndrome. The results show that five out of seven patients with continent ileostomy had malabsorption of vitamin $\mathbf{B}_{12}$, whereas subnormal values of vitamin $\mathbf{B}_{12}$ absorption were found in two patients with conventional ileostomy (Table). The evidence of a stagnant loop syndrome in four of the five patients with continent ileostomy and $\mathrm{B}_{12}$-malabsorption (patients 1, 2, 3, and 4) is as follows:

The malabsorption was associated with overgrowth of anaerobic bacteria (Fig. 1). The patients also showed improved absorption of vitamin $B_{12}$ and fat after treatment with oral lincomycin. At the same time the concentration of Bacteroides in the ileal contents markedly decreased (Fig. 2). Bacteroides fragilis is the predominant organism of the normal intestinal flora. $B$. fragilis, which has an absolute need for vitamin $\mathbf{B}_{12}$ (Varel and Bryant, 1974), may play a major role in the development of the vitamin $B_{12}$ malabsorption associated with bacterial overgrowth. There is also stagnation of the intestinal contents, as these are stored for long periods in the intraabdominal ileal reservoir (Brandberg et al., 1972).

After an oral dose of $[1-14 \mathrm{C}]$ glycocholic acid there was no difference in the absorption coefficient for radioactivity $\left({ }^{14} \mathrm{C}\right)$ in the two groups of patients (Table). If the ${ }^{14} \mathrm{C}$-label is taken as representing the bile acid, the absorption coefficient gives an estimate of the absorption of the bile acid. Nevertheless, it is uncertain whether the excreted radioactivity can give an estimate of the glycocholic acid absorption. The ${ }^{14} \mathrm{C}$-label is on the glycine, and some of the label excreted could be glycine and not glycocholic acid. The cumulative ${ }^{14} \mathrm{CO}_{2}$-expiration (breath test for deconjugated bile acids) was increased in only two patients with continent ileostomy (patients 3 and 4) compared with the patients with conventional ileostomy. The reason why the breath test showed normal value in the two other patients with the stagnant loop syndrome (patients 1 and 2) is not certain. Possibly the result of the breath test may be influenced by the lack of colon. Thus, in the patients with conventional ileostomy, the cumulative ${ }^{14} \mathrm{CO}_{2}$ expiration was less than in our control patients $(\mathrm{P}<0.02)$.

Also in two other patients with continent ileostomy (nos. 5 and 6) there was evidence that the bacterial flora interfered with the intestinal absorption. The absorption of vitamin $B_{12}$, which was close to the lower limit of the normal range, markedly increased after treatment with oral antibiotics. At the same time the excretion of faecal fat decreased.

In patient no. 7 who had a continent ileostomy there was no evidence of a stagnant loop syndrome. This patient had $\mathbf{B}_{12}$-malabsorption but the absorption remained abnormal after antibiotic treatment. The cause of the malabsorption in this patient is uncertain.

\section{References}

Brandberg, A., Kock, N. G., and Philipson, B. (1972). Bacterial flora in intraabdominal ileostomy reservoir. Gastroenterology, 63, 413-416.

Closs, K., and Pihl, A. (1941). Methode zur Bestimmung von Fett und Fettsäuren in den Faeces. Klinische Wochenschrift, 20, 224-225.

Drasar, B. S. (1967). Cultivation of anaerobic intestinal bacteria. Journal of Pathology and Bacteriology, 94, 417427.

Finegold, S. M., Sugihara, P. T., and Sutter, V. L. (1971). Isolation of Anaerobes, p. 99. Edited by D. A. Shapton and R. G. Board. Academic Press: London.

Fromm, H., and Hofmann, A. F. (1971). Breath test for altered bile-acid metabolism. Lancet, 2, 621-625.

Hydén, S. K. (1955). A turbidometric method for the determination of higher polyethylene glycols in biological materials. Kungliga Landbrukshögskolans annaler, 22, 139-145.

Jagenburg, R., Dotevall, G., Kewenter, J., Kock, N. G., and Philipson, B. (1971). Absorption studies in patients with 'intraabdominal reservoirs' and in patients with conventional ileostomies. Gut, 12, 437-441.

Jagenburg, R., Kock, N. G., and Philipson, B. (1975). Vitamin $\mathbf{B}_{12}$ absorption in patients with continent ileostomy. Scandinavian Journal of Gastroenterology, 10, 141-144.

Kock, N. G. (1969). Intra-abdominal 'reservoir' in patients with permanent ileostomy. Archives of Surgery, 99, 223-231.

Philipson, B., Brandberg, A.., Jagenburg, R., Kock, N. G., Lager, I., and Åhrén, C. (1975). Mucosal morphology, bacteriology and absorption in intraabdominal ileostomy reservoir. Scandinavian Journal of Gastroenterology, 10, 145-153.

Schjønsby, H. (1972). The effect of bacteria on intestinal uptake of vitamin $B_{12}$. I. Effect of cultures of blind-loop contents. Scandinavian Journal of Gastroenterology, 7, 119-128.

Sutter, V. L., Vargo, V. L., and Finegold, S. M. (1975). 
Wadsworth Anaerobic Bacteriology Manual, 2nd edn. Anaerobic Bacteriology Laboratory, Wadsworth Hospital Center, University of California: Los Angeles.

Tabaqchali, S. (1970). The pathophysiological role of small intestinal bacterial flora. Scandinavian Journal of Gastroenterology, 5, suppl. 6, 139-163.

Varel, V. H., and Bryant, M. P. (1974). Nutritional features of Bacteroides fragilis subsp. fragilis. Applied Microbiclogy, 28, 251-257.

Woodbury, J. F., and Kern, F., Jr. (1971). Fecal excretion of bile acids: a new technique for studying bile acid kinetics in patients with ileal resection. Journal of Clinical Investigation, 50, 2531-2540. 